\title{
Ontogenetic dietary shifts of largemouth bass do not increase trophic position in a shallow eutrophic lake in Japan
}

\author{
Natsuru Yasuno ${ }^{1 * \dagger}+$ Yasufumi Fujimoto ${ }^{2}$, Tetsuo Shimada ${ }^{2}$, Shuichi Shikano ${ }^{3}$ and \\ Eisuke Kikuchi $^{4}$ \\ ${ }^{1}$ Graduate School of Life Sciences, Tohoku University 2-1-1 Katahira, Aoba-ku, Sendai, Miyagi 980-8577, Japan \\ 2 Miyagi Prefectural Izunuma-Uchinuma Environmental Foundation 17-2 Shikimi, Wakayanagi, Kurihara, Miyagi, 989-5504, \\ Japan \\ 3 Center for Northeast Asian Studies, Tohoku University 41 Kawauchi, Aoba-ku, Sendai, Miyagi 980-8576, Japan \\ ${ }^{4}$ Environmental Education Center, Miyagi University of Education 149 Aramaki Aza Aoba, Aoba-ku, Sendai, 980-0845, Japan
}

Received 19 April 2016; Accepted 5 September 2016

\begin{abstract}
The trophic positions of top predators can provide useful information for estimating the length of food chains and for assessing the impacts of invasive species or the bioaccumulation of harmful compounds. In aquatic ecosystems, large carnivorous fishes may change their trophic positions ontogenetically. We used stable carbon and nitrogen isotope ratios to test the hypothesis that the trophic positions of largemouth bass, top predators in Lake Izunuma, Japan, would increase with total length (TL) as a result of ontogenetic shifts in diet. Results from a stable isotope analysis in $\mathrm{R}$ mixing model indicated that largemouth bass $<100 \mathrm{~mm}$ TL fed mostly on zooplankton and small omnivorous fishes, while individuals from 100 to $199 \mathrm{~mm}$ TL size class relied more heavily on small omnivorous fishes. Red swamp crayfish Procambarus clarkii were a major food source for largemouth bass $\geq 200 \mathrm{~mm}$ TL. However, the trophic positions of largemouth bass did not increase with the dietary shift from zooplanktivory to piscivory, and actually decreased when larger fish shifted towards feeding on red swamp crayfish. In Lake Izunuma, the trophic positions of small omnivorous fishes and red swamp crayfish were not higher than those of zooplankton. This explains why the largest largemouth bass occupied lower trophic positions than smaller individuals. Our results suggest that the body size of carnivorous fishes should be taken into consideration when using their trophic positions as top predators to evaluate aquatic systems.
\end{abstract}

Key words: Stable isotope / invasive species / SIAR / piscivory / crayfish

\section{Introduction}

Food-web analysis is commonly used to study the complex trophic interactions between organisms and organic matter flow within ecosystems (Hairston and Hairston, 1993). Determining the trophic positions of organisms (which are continuous variables) and the position they occupy in food chains is a critical step for investigating these interactions (e.g., Post, 2002a, 2002b; Vander Zanden and Vadeboncoeur, 2002). In aquatic ecosystems, the trophic positions of fish species can be used to assess the negative impacts of invasive species on native aquatic communities (Vander Zanden et al., 1998),

*Corresponding author: plumosussia@yahoo.co.jp

$\dagger$ Current address: Sendai City Hall, 3-7-1 Kokubun-cho, Aoba-ku, Sendai, Miyagi, 980-0803, Japan to measure contaminant bioaccumulation (Rasmussen et al., 1990) and to improve fishery productivity (Pauly and Christensen, 1995).

Stable carbon and nitrogen isotope ratios $\left(\delta^{13} \mathrm{C}\right.$ and $\delta^{15} \mathrm{~N}$ ) have been widely used to investigate food-web structure in a range of aquatic ecosystems (e.g., Vander Zanden and Vadeboncoeur, 2002; Jones and Waldron, 2003; Vander Zanden et al., 2011) because the respective ratios in an organism reflect its diet, providing insight into its feeding history in the long term. Trophic positions of consumers can be estimated from their $\delta^{15} \mathrm{~N}$ values, which are typically enriched by 3-4\% through trophic transfer (Post, 2002b; Vanderklift and Ponsard, 2003). $\delta^{13} \mathrm{C}$ values can provide information on an organism's primary carbon source because these values change little through trophic transfer (DeNiro and Epstein, 1978; Fry and Sherr, 1984; Post, 2002b). 
Body size has been recognized as a key trait of aquatic consumers since it influences predator-prey interactions (Persaud et al., 2012). Previous studies in fishes have reported an increase in trophic position with increased body size as a result of ontogenetic dietary shifts (Kline et al., 1998; Vander Zanden et al., 1999; Jennings et al., 2001). Because larger carnivorous fish have correspondingly larger gape sizes and can thus capture larger prey (Shelton et al., 1979), large individuals of piscivorous fish species are often recognized as top predators in aquatic ecosystems (Vander Zanden and Vadeboncoeur, 2002; Vander Zanden et al., 2004; Doi et al., 2009). However, some studies have reported that the trophic positions of fishes do not always increase with body size (Wang et al., 2011; Persaud et al., 2012).

The largemouth bass Micropterus salmoides is a piscivorous fish native to North America. Largemouth bass have been introduced outside of their native range for sport fishing (Hickley et al., 1994; García-Berthou, 2002; Yonekura et al., 2004; Jang et al., 2006; Magoro et al., 2015) and have greatly altered native fish communities through predation (Azuma and Motomura, 1998; Whittier and Kincaid, 1999; Takahashi et al., 2001; Yonekura et al., 2004; Jang et al., 2006). Consequently, largemouth bass have become top predators in many bodies of water in Japan (Yonekura et al., 2004; Maezono et al., 2005). Estimation of the trophic position of invasive piscivores is crucial to assessing their negative impacts, including predation and competition with native communities (Vander Zanden et al., 1999; Correa et al., 2012; Feiner et al., 2013). Different size classes of largemouth bass could have different effects on native aquatic communities due to ontogenetic diet shifts. However, the relationship between the trophic position and body size of largemouth bass in Japan is still unclear. In addition, the contamination of freshwater carnivorous fishes with radioactive cesium has been investigated in the wake of the serious accident at the Fukushima Dai-ichi Nuclear Power Plant (Arita et al., 2015; Matsuda et al., 2015). Freshwater carnivores show higher radioactive cesium levels than do omnivores and herbivores, likely due to bioaccumulation through the food chain (Mizuno and Kubo, 2013). Therefore, the relationship between trophic positions and body size of largemouth bass could provide useful information in assessing the bioaccumulation of radioactive cesium.

This study was conducted at Lake Izunuma, which is shallow and relatively small, and representative of the bodies of water into which largemouth bass are frequently introduced. Our objectives were (1) to estimate trophic positions, (2) to determine the major prey organisms of largemouth bass in each body size class, and (3) to establish the relationship between trophic positions and body size using stable carbon and nitrogen isotope ratios. We hypothesized that the trophic positions of largemouth bass, the top predators in Lake Izunuma, Japan, would increase with total length as a result of ontogenetic shifts in diet.

\section{Materials and methods}

\section{Study area}

Lake Izunuma in temperate northeastern Honshu, Japan (Fig. 1) is eutrophic (Yasuno et al., 2009), polymictic and shallow (Table 1) (Shidara, 1992). The lake is largely dominated by macrophytes (mainly lotus, Nelumbo nucifera and other floating, leaved macrophytes). Benthic algae and submerged plants have restricted distributions, likely due to high water turbidity. Largemouth bass were introduced to Lake Izunuma for angling and were first caught in 1996; they subsequently became the top predator species in the ecosystem (Takahashi et al., 2001). Until 1995, the annual harvest of native fish in Lake Izunuma exceeded 30 tons and consisted primarily of cyprinids (Takahashi et al., 2001). Since then, the number of largemouth bass has increased, while other fish species have decreased sharply. The fish community is still dominated by small cyprinid species, mainly Gnathopogon elongates elongates and Pseudorasbora parva. These two species of cyprinids make up $70 \%$ of the fish community in the lake, while largemouth bass account for $8.8 \%$ (Fujimoto et al., 2008).

\section{Sample collection}

We collected largemouth bass in May 2006, using gill nets, and in December 2006 using fyke nets near the south shore (Fig. 1). Because largemouth bass spawned by the south shore, we were easily able to catch adult individuals ( $>300 \mathrm{~mm}$ TL) there using gill nets. From MayDecember 2006, we also used fyke nets to catch small omnivorous fishes and red swamp crayfish Procambarus clarkii, which are potential prey for largemouth bass. A fyke net is a type of fixed net that is dustpan-shaped and resembles a trawl net (mesh size: $5 \mathrm{~mm}$, length: $5 \mathrm{~m}$, diameter: $0.6 \mathrm{~m}$ ) with long wings (mesh size: $10 \mathrm{~mm}$, length: $30 \mathrm{~m}$, depth: $1.8 \mathrm{~m}$ ). Fyke nets were set for $24 \mathrm{~h}$. We measured the TL of largemouth bass and potential omnivorous prey fishes $<200 \mathrm{~mm}$ TL to the nearest $1 \mathrm{~mm}$, and measured individuals $>200 \mathrm{~mm}$ TL to the nearest $10 \mathrm{~mm}$ in the laboratory. We then dissected each fish and removed a sample of dorsal muscle tissue for freeze-drying and subsequent stable isotope analysis. Two species of dragonfly (Epophthalmia elegans and Sinictinogomphus clavatus) and a species of snail (Radix auricularia japonica) were captured using dip nets near the south shore in June 2006. We used the whole bodies of dragonflies, while we removed muscle tissue samples of snails and red swamp crayfish for freeze-drying and subsequent stable isotope analysis.

To determine stable isotope ratios, we ground freezedried samples of all invertebrates and fishes, homogenized them in a pre-combusted $\left(500{ }^{\circ} \mathrm{C}, 2 \mathrm{~h}\right)$ agate mortar and pestle, and then treated them with a chloroform: methanol mixture $(2: 1, \mathrm{v} / \mathrm{v})$ to remove lipids. The samples were concentrated onto Whatman $\mathrm{GF} / \mathrm{C}$ glass filters 

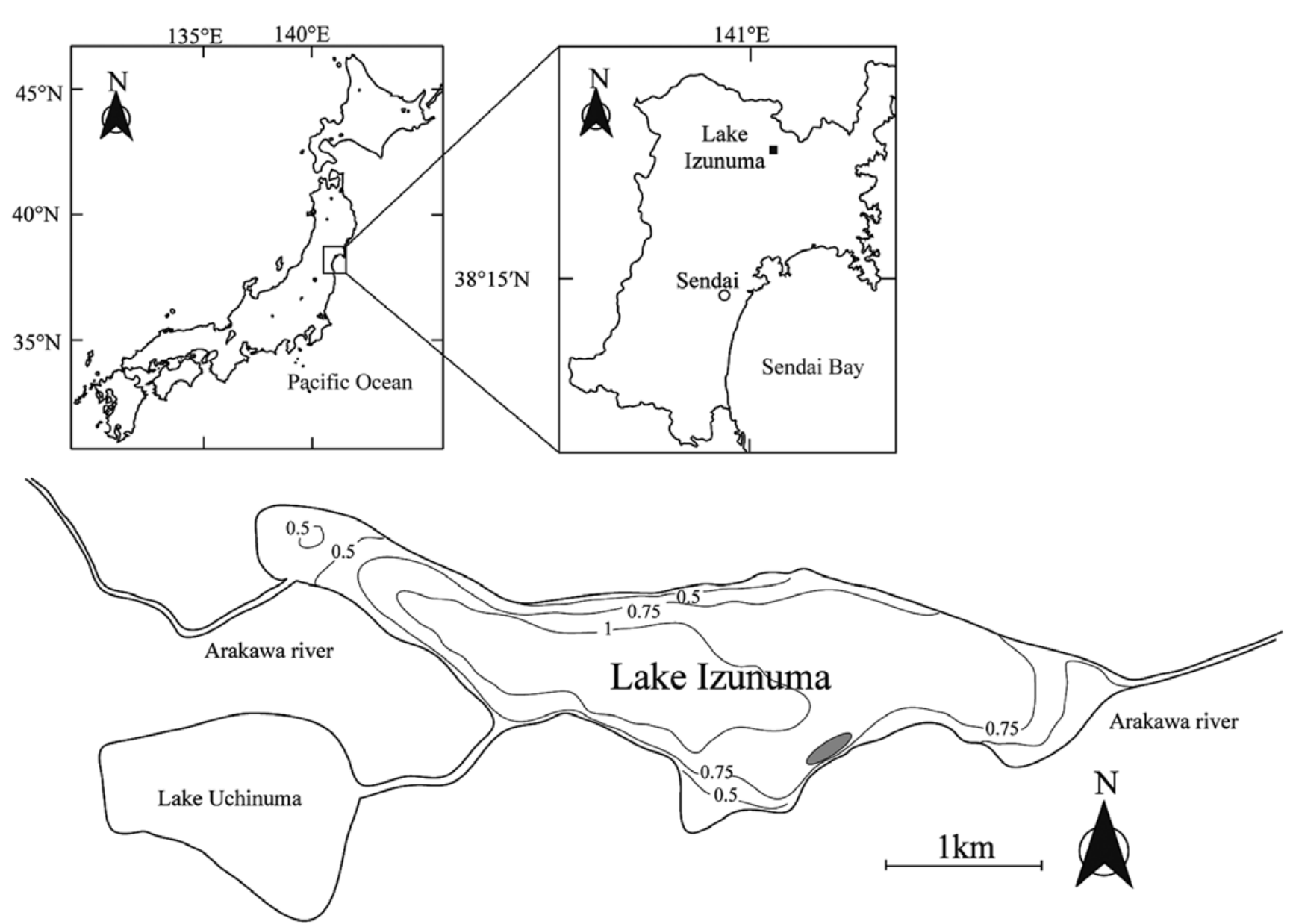

Fig. 1. Sampling locations in Lake Izunuma. Solid lines indicate the isobath in meters. We collected fishes within the gray area by setting two or three gillnets or fyke nets.

Table 1. Characteristics of Lake Izunuma.

\begin{tabular}{ll}
\hline Location & $38^{\circ} 43^{\prime} \mathrm{N}, 141^{\circ} 06^{\prime} \mathrm{E}$ \\
\hline Altitude $(\mathrm{m}$ above sea level) & $6^{\mathrm{a}}$ \\
Area $\left(\mathrm{km}^{2}\right)$ & $3.69^{\mathrm{a}}$ \\
Max depth $(\mathrm{m})$ & $1.6^{\mathrm{a}}$ \\
Chl. $a\left(\mu \mathrm{g} . \mathrm{L}^{-1}\right)$ & $36.1^{\mathrm{b}}$ \\
Secchi depth $(\mathrm{m})$ & $0.6^{\mathrm{b}}$ \\
pH & $7.5^{\mathrm{c}}$ \\
Conductivity $\left(\mu \mathrm{S} . \mathrm{cm}^{-1}\right)$ & $40.4^{\mathrm{c}}$ \\
\hline
\end{tabular}

ashidara (1992).

${ }^{\text {b}}$ Yasuno et al. (2009).

'Yasuno unpublished data (from July 2006 to June 2007).

(pre-combusted at $500{ }^{\circ} \mathrm{C}$ for $2 \mathrm{~h}$ ), which were then freezedried.

\section{Stable isotope analyses}

The stable isotope ratios of the samples were measured with a Finnigan MAT Delta-plus mass spectrometer (Thermo Finnigan, San Diego, CA, USA) connected to an NA2500 elemental analyzer (CE Instruments, Wigan,
UK). Stable isotope ratios were presented using the standard delta notation:

$$
\delta^{13} \mathrm{C} \text { or } \delta^{15} \mathrm{~N}=\left(R_{\text {sample }} / R_{\text {standard }}-1\right) \times 1000(\% 0)
$$

where $R={ }^{13} \mathrm{C} /{ }^{12} \mathrm{C}$ or ${ }^{15} \mathrm{~N} /{ }^{14} \mathrm{~N}$. We report isotope ratio values relative to the following standards: Vienna Pee-Dee belemnite for $\delta^{13} \mathrm{C}$ and atmospheric nitrogen gas for $\delta^{15} \mathrm{~N}$. The analytical error of the analyzer was within $\pm 0.1 \%$ for carbon and $\pm 0.2 \%$ or nitrogen.

\section{Diet assessment}

\section{Model inputs}

We used the isotopic data of largemouth bass collected in this study and cited the data of age- $0+$ largemouth bass from Yasuno et al. (2012); then, we divided largemouth bass into four size classes (TL $<100,100-199,200-299$ and $\geq 300 \mathrm{~mm}$ ). Given that largemouth bass forage on various organisms such as fishes, crustaceans, aquatic insects and zooplankton (Keast and Eadie, 1985; Olson, 1996), we assumed four end members of their potential food sources: eight species of small omnivorous fishes, red 
swamp crayfish $P$. clarkii, benthic invertebrates (two species of dragonfly and larval chironomids) and zooplankton. We collected three species of small omnivorous fishes, red swamp crayfish and the two species of dragonfly used in this study. We used reference isotopic data for the other five species of small omnivorous fishes and zooplankton from Yasuno et al. (2016) and for larval chironomids from Yasuno et al. (2013). Largemouth bass generally forage on zooplankton during their early lifehistory ( < ca. $100 \mathrm{~mm}$ TL) (Keast and Eadie, 1985; Olson, 1996; Takahashi et al., 2001) and zooplanktivorous individuals are often <c.a. $200 \mathrm{~mm}$ long (Ha et al., 2015). In contrast, red swamp crayfish are typically too large for small individuals $(<200 \mathrm{~mm} \mathrm{TL})$ to capture (Schramm and Maceina, 1986; Hickley et al., 1994; García-Berthou, 2002; Wheeler and Allen, 2003; Torigoe and Shiraiwa, 2010). In our own experience, we have often observed red swamp crayfish in the stomachs of largemouth bass $>200 \mathrm{~mm}$ TL in Lake Izunuma, but we have never found them in the stomachs of smaller individuals (N. Yasuno, personal observation). Therefore, small benthic invertebrates, zooplankton and small omnivorous fishes were assumed to be potential food for largemouth bass $<200 \mathrm{~mm} \mathrm{TL}$, while benthic invertebrates, small omnivorous fishes and red swamp crayfish were assumed to be prey for individuals $>200 \mathrm{~mm}$ TL.

\section{Bayesian mixing model}

The relative contributions of these potential food sources to the diets of largemouth bass were estimated using SIAR (Stable Isotope Analysis in R; R Development Core Team, 2015). Conventional isotope mixing models can calculate relative dietary contributions from the mean isotopic values of food sources and isotopic discrimination through trophic transfer (Phillips and Gregg, 2001). However, uncertainties such as variation around the mean isotope values of food sources (prey) and fractionation factors may affect the solution of the model. The SIAR isotope mixing model uses Bayesian inference and has the advantage of allowing variation and uncertainties to propagate throughout the model, with the output better reflecting the natural variability within a system. The SIAR model was fit using Markov chain Monte Carlo methods, which used a Dirichlet prior distribution to simulate dietary proportions of food sources that were consistent with the data (Parnell et al., 2010). We assumed that the isotopic discrimination for nitrogen and carbon were $3.23 \pm 0.41$ and $0.94 \pm 1.13 \%$, respectively (Vander Zanden and Rasmussen, 2001). The SIAR mixing model ran 500000 iterations, discarding the first 50000 samples.

\section{Estimation of trophic positions}

The trophic positions of consumers can be estimated from their $\delta^{15} \mathrm{~N}$ values and a baseline (typically from a primary producer or consumer). Lake food-webs are typically supported by phytoplankton in the pelagic zone, and macrophytes and their epiphytic algae in the littoral zone (Scheffer, 1998). Because the isotopic baselines of primary producers may differ, it is important to consider the contribution of each food chain pathway to consumers in order to more accurately estimate their trophic positions. Therefore, we used cladoceran zooplankton and snails as pelagic and littoral isotopic baselines, respectively, to estimate the trophic levels of consumers. Longlived primary consumers, such as filter-feeding mussels (pelagic consumers) and snails (littoral consumers), are often used as isotopic baselines because they integrate the temporal fluctuations of primary producers (Cabana and Rasmussen, 1996; Post, 2002b). However, the unionid mussel Cristaria plicata in Lake Izunuma has been shown to ontogenetically increase its stable nitrogen isotope ratios, indicating that large individuals could transition to secondary consumers (Yasuno et al., 2014). Therefore, we used $\delta^{15} \mathrm{~N}$ values from filter-feeding cladoceran zooplankton as a pelagic baseline instead of mussels. We estimated the trophic positions of primary consumers, largemouth bass and their potential prey species, including copepod zooplankton, eight species of small omnivorous fishes and red swamp crayfish, using the following formulas:

Trophic position

$$
\begin{aligned}
& =\left(\delta^{15} \mathrm{~N}_{\text {consumer }}-\left[a \times \delta^{15} \mathrm{~N}_{\text {snail }}+(1-a) \times \delta^{15} \mathrm{~N}_{\mathrm{zp}}\right]\right) / \Delta N+2 \\
a & =\left(\delta^{13} \mathrm{C}_{\text {consumer }}-\delta^{13} \mathrm{C}_{\mathrm{zp}}\right) /\left(\delta^{13} \mathrm{C}_{\text {snail }}-\delta^{13} \mathrm{C}_{\mathrm{zp}}\right)
\end{aligned}
$$

where $\Delta N$ represents the isotopic discrimination of ${ }^{15} \mathrm{~N}$ (assumed value previously mentioned). The subscripts "consumer," "snail" and "zp" represent consumers (largemouth bass or their potential prey species), littoral isotopic baseline species ( $R$. auricularia japonica) and pelagic isotopic baseline species (cladoceran zooplankton), respectively. We rounded " $a$ " to 1 or 0 if the values were slightly $>1$ or $<0$, respectively. Differences in mean trophic positions between size classes of largemouth bass were evaluated using the Kruskal-Wallis test. Post hoc analysis of differences between size classes was conducted using the Steel-Dwass test.

\section{Relationships between isotopic ratios, trophic positions and body size}

We evaluated the relationships between the $\delta^{13} \mathrm{C}$ of largemouth bass and their TL using Spearman's correlation coefficient. We also tested the relationship between their trophic position and TL using the same method.

\section{Results}

\section{Stable isotope ratios of largemouth bass and their potential prey}

The $\delta^{13} \mathrm{C}$ and $\delta^{15} \mathrm{~N}$ ratios of largemouth bass varied considerably among individuals, ranging from -32.2 to 
Table 2. Stable isotope values of largemouth bass.

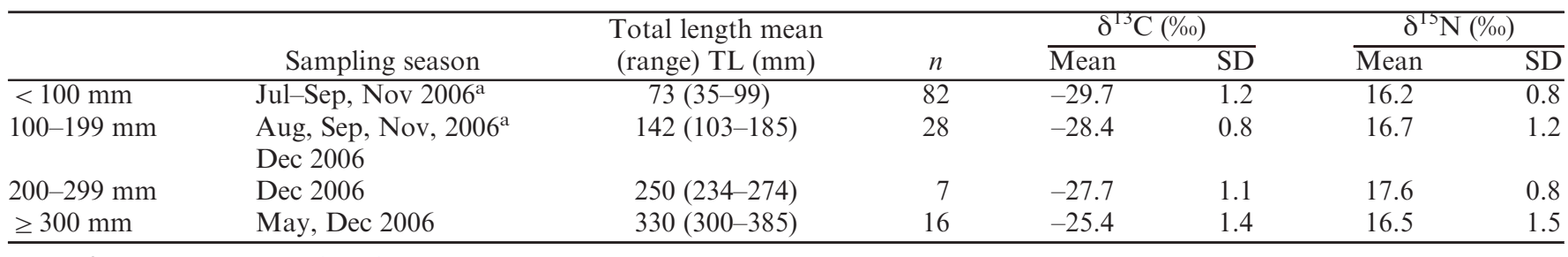

${ }^{\mathrm{a}}$ Data from Yasuno et al. (2012).

Table 3. Stable isotope values of potential prey for largemouth bass.

\begin{tabular}{|c|c|c|c|c|c|c|c|}
\hline \multirow[b]{2}{*}{ Samples } & \multirow[b]{2}{*}{ Sampling season } & \multirow{2}{*}{$\begin{array}{l}\text { Size range } \\
(\mathrm{mm} \mathrm{TL})\end{array}$} & \multirow[b]{2}{*}{$n$} & \multicolumn{2}{|c|}{$\delta^{15} \mathrm{C}(\%)$} & \multicolumn{2}{|c|}{$\delta^{15} \mathrm{~N}(\%)$} \\
\hline & & & & $\overline{\text { Mean }}$ & $\overline{\mathrm{SD}}$ & $\overline{\text { Mean }}$ & $\overline{\mathrm{SD}}$ \\
\hline \multicolumn{8}{|l|}{ Snail } \\
\hline Radix auricularia japonica & Jun 2006 & & 3 & -26.1 & 1.1 & 12.6 & 0.4 \\
\hline Zooplankton $^{\mathrm{a}}$ & & & 17 & -31.5 & 1.2 & 12.1 & 2.1 \\
\hline Copepod zooplankton & & & 9 & -31.9 & 1.1 & 13.8 & 1 \\
\hline Eodiaptomus japonicus & Jun-Sep 2006 & & 4 & -31.2 & 0.8 & 13.3 & 0.9 \\
\hline Eodiaptomus japonicus + Cyclops sp. & Oct 2006 & & 1 & -32.7 & & 13.7 & \\
\hline Cyclops sp. & Nov, Dec 2006 & & 4 & -32.3 & 1.2 & 14.3 & 1.0 \\
\hline Cladoceran zooplankton & & & 8 & -31.1 & 1.2 & 10.1 & 1.1 \\
\hline Sida crystalline & Jun, Jul, Sep 2006 & & 5 & -31.0 & 0.7 & 10.0 & 1.1 \\
\hline Sida crystalline + Diaphanosoma brachyurum & Jul, Aug 2006 & & 2 & -30.7 & & 11 & \\
\hline Diaphanosoma brachyurum & Sep 2006 & & 1 & -32.4 & & 9.1 & \\
\hline Benthic invertebrates & & & 46 & -35.2 & 6.1 & 10.3 & 2.5 \\
\hline Chironomus plumosus ${ }^{\mathrm{b}}$ & May-Dec 2006 & & 41 & -35.8 & 6.2 & 10.2 & 2.6 \\
\hline Epophthalmia elegans & Jun 2006 & & 4 & -29.5 & 2.4 & 12.6 & 0.4 \\
\hline Sinictinogomphus clavatus & Jun 2006 & & 1 & -35.5 & & 10.5 & \\
\hline \multicolumn{8}{|l|}{ Red swamp crayfish } \\
\hline Procambarus clarkia & May-Jul 2006 & & 6 & -26.5 & 1.0 & 13.6 & 0.9 \\
\hline Small omnivorous fishes & & & 74 & -27.8 & 1.8 & 13.6 & 1.5 \\
\hline Gnathopogon elongatus elongatus ${ }^{\mathrm{a}}$ & Jul-Sep 2006 & $43-80$ & 15 & -29.0 & 0.5 & 14.8 & 1.0 \\
\hline Pseudorasbora parva & Jul-Sep 2006 & $34-102$ & 15 & -28.6 & 0.8 & 14.9 & 0.8 \\
\hline Biwia zezera $^{\mathrm{a}}$ & Jul-Sep 2006 & $32-62$ & 8 & -28.3 & 1.0 & 13.1 & 0.8 \\
\hline Acheilognathus rhombeus ${ }^{\mathrm{a}}$ & Jul-Sep 2006 & $34-85$ & 20 & -26.4 & 2.0 & 12.0 & 1.0 \\
\hline Tridentiger obscurus ${ }^{\mathrm{a}}$ & Jul 2006 & $31-35$ & 3 & -28.3 & 0.7 & 14.0 & 0.5 \\
\hline Sarcocheilichthys variegatus microoculus & Sep 2006 & $68-93$ & 5 & -26.3 & 3.1 & 13.3 & 1.6 \\
\hline Carassius sp. & Jul 2006 & $44-48$ & 4 & -28.7 & 1.5 & 13.7 & 1.2 \\
\hline Opsariichthys platypus & Jul 2006 & $54-70$ & 4 & -26.4 & 1.0 & 12.4 & 0.6 \\
\hline
\end{tabular}

a Data from Yasuno et al. (2016).

${ }^{b}$ Data from Yasuno et al. (2013).

$-22.0 \%$ and from 14.0 to $18.9 \%$, respectively. Bass that were $>300 \mathrm{~mm}$ TL were the most $\delta^{13} \mathrm{C}$-enriched, while bass $<100 \mathrm{~mm}$ TL were the most $\delta^{13} \mathrm{C}$-depleted (Table 2). The $200-299 \mathrm{~mm}$ TL size class was more enriched in $\delta^{15} \mathrm{~N}$ than any other size class (Table 2).

The potential prey of largemouth bass (small omnivorous fishes, red swamp crayfish, benthic invertebrates and zooplankton) had distinctive mean $\delta^{13} \mathrm{C}$ and $\delta^{15} \mathrm{~N}$ values in Lake Izunuma (Table 3). The mean $\delta^{13} \mathrm{C}$ value of red swamp crayfish was more enriched than those of other food sources and similar to that of grazing snails $R$. auricularia japonica. By contrast, the mean $\delta^{13} \mathrm{C}$ value of benthic invertebrates was the most depleted among potential prey species. The mean $\delta^{13} \mathrm{C}$ values of small omnivorous fishes and zooplankton had intermediate values among the potential prey species, although the mean value of small omnivorous fishes indicated more enrichment than that of zooplankton. The mean $\delta^{15} \mathrm{~N}$ values of small omnivorous fishes and red swamp crayfish were more enriched than those of zooplankton and benthic invertebrates. Among zooplankton, the mean $\delta{ }^{15} \mathrm{~N}$ values of copepods and cladocerans were the most enriched and the most depleted values, respectively, among potential prey species.

\section{Fractional dietary contribution of food sources}

The SIAR mixing model showed the dietary differences among size classes of largemouth bass (Fig. 2). Among the potential prey species, zooplankton contributed more to the diet of the smallest size class $(<100 \mathrm{~mm}$ TL; 95\% credibility interval, 33-52\%) than to fish 100-199 mm TL (20-51\%) (Fig. 3), while small omnivorous fishes were the 

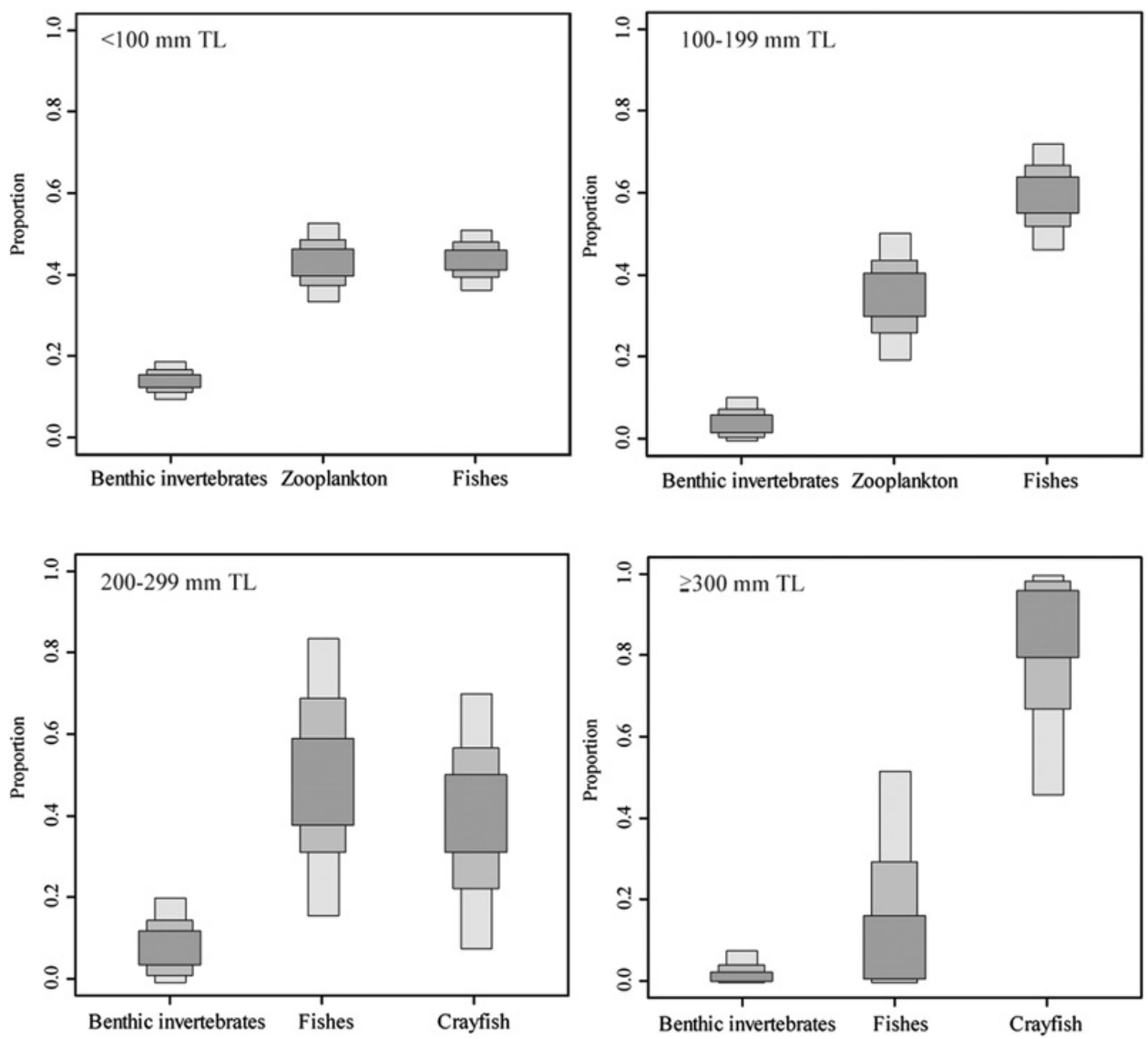

Fig. 2. Boxplots derived from the stable isotope analysis in $\mathrm{R}$ mixing model showing the contribution of different potential food sources to the diets of four largemouth bass size classes using $\delta^{13} \mathrm{C}$ and $\delta^{15} \mathrm{~N}$ values. Fishes = small omnivorous fishes; crayfish $=$ red swamp crayfish. The proportions show credibility intervals plotted at 95,75 and $25 \%$ credibility intervals.

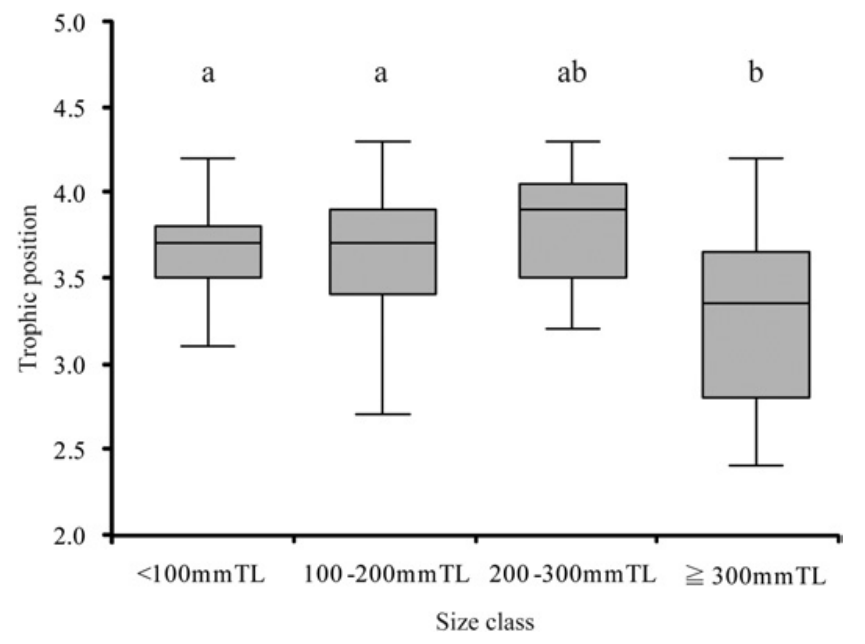

Fig. 3. Trophic positions of four largemouth bass size classes. Shared lower-case letters indicate that no significant differences were found in the trophic positions at $P<0.05$. Different letters indicate significant differences.

most important prey items for both of these size classes (36-51 and 47-72\% for fish $<100 \mathrm{~mm}$ TL and 100-199 mm TL, respectively). These results were consistent with previous reports that largemouth bass consume zooplankton during their early life-history (<ca. $100 \mathrm{~mm}$ long) (Keast and Eadie, 1985; Olson, 1996).

We found that red swamp crayfish did contribute more to the diet of the largest size class $(\geq 300 \mathrm{~mm}$ TL; $46-100 \%)$ than small omnivorous fishes $(0-51 \%)$. The 200-299 mm TL size class depended both on small omnivorous fishes (16-84\%) and red swamp crayfish $(8-71 \%)$. Benthic invertebrates rarely contributed to the diets of any size classes.

\section{The trophic positions of largemouth bass and their potential prey}

Largemouth bass occupied higher trophic positions than other organisms (Fig. 3, Table 4). The trophic positions of largemouth bass $\geq 300 \mathrm{~mm}$ TL were significantly lower than those of largemouth bass $<100$ mm TL and 100-199 mm TL $(P<0.05$, Fig. 3$)$.

Among the potential prey species of bass, copepod zooplankton, which was the dominant zooplankton taxon and small omnivorous fishes ( $G$. elongates elongates, $P$. parva and $T$. obscurus) occupied a trophic position of approximately 3, suggesting that they are secondary consumers (Table 4). The trophic positions of A. rhombeus 
Table 4. Trophic positions of potential prey for largemouth bass.

\begin{tabular}{|c|c|c|c|}
\hline \multirow[b]{2}{*}{ Samples } & \multirow[b]{2}{*}{$n$} & \multicolumn{2}{|c|}{ Trophic position } \\
\hline & & Mean & $\mathrm{SD}$ \\
\hline \multicolumn{4}{|l|}{ Snail } \\
\hline Radix auricularia japonica & 3 & $2.0^{\mathrm{a}}$ & - \\
\hline Zooplankton & 17 & 2.6 & 0.6 \\
\hline Copepod zooplankton & 9 & 3.1 & 0.3 \\
\hline Cladoceran zooplankton & 8 & $2.0^{\mathrm{a}}$ & - \\
\hline \multicolumn{4}{|l|}{ Red swamp crayfish } \\
\hline Procambarus clarkii & 6 & 2.5 & 0.3 \\
\hline Small omnivorous fishes & 74 & 2.6 & 0.6 \\
\hline Gnathopogon elongatus elongatus & 15 & 3.1 & 0.3 \\
\hline Pseudorasbora parva & 15 & 3.1 & 0.3 \\
\hline Biwia zezera & 8 & 2.5 & 0.3 \\
\hline Acheilognathus rhombeus & 20 & 2.0 & 0.5 \\
\hline Tridentiger obscurus & 3 & 2.8 & 0.3 \\
\hline Sarcocheilichthys variegatus microoculus & 5 & 2.4 & 0.4 \\
\hline Carassius sp. & 4 & 2.7 & 0.6 \\
\hline Opsariichthys platypus & 4 & 2.0 & 0.2 \\
\hline
\end{tabular}

aTrophic positions of snail and cladoceran zooplankton were assumed at 2.0.

and Opsariichthys platypus were approximately 2, suggesting that they are primary consumers (herbivores). Other small omnivorous fishes and red swamp crayfish had intermediate trophic levels between 2 and 3. Small omnivorous fishes (mean $\pm 1 \mathrm{SD} ; 2.6 \pm 0.6$ ) and zooplankton $(2.6 \pm 0.6)$ as a whole had intermediate trophic positions that were similar to that of red swamp crayfish $(2.5 \pm 0.3)$.

\section{Relationships between isotopic ratios, trophic positions and body size}

The $\delta^{13} \mathrm{C}$ values of largemouth bass correlated significantly with TL ( $\mathrm{rs}=0.652, P<0.001$, Fig. 4(a)), indicating ontogenetic dietary shifts toward more $\delta^{13} \mathrm{C}$ enriched food sources. Their trophic positions correlated negatively with TL ( $\mathrm{rs}=-0.182, P<0.05$, Fig. 4(b)).

\section{Discussion}

\section{Dietary analyses of largemouth bass using stable isotopes}

Piscivorous fishes typically experience ontogenetic diet shifts, either moving directly from zooplanktivory to piscivory, or including a period of insectivory (Keast, 1985; Olson, 1996). Previous studies have reported that largemouth bass forage on aquatic insects (e.g., Hickley et al., 1994; García-Berthou, 2002). In Lake Izunuma, however, benthic insects (larval chironomids and dragonflies) were rarely consumed by any size class of largemouth bass (Fig. 3). In fact, Takahashi et al. (2001) reported that the stomach contents of juvenile largemouth bass contained $<5 \%$ aquatic insects. Because largemouth bass are opportunistic feeders (Schindler et al., 1997; Wasserman et al., 2011; Magoro et al., 2015) and find prey visually
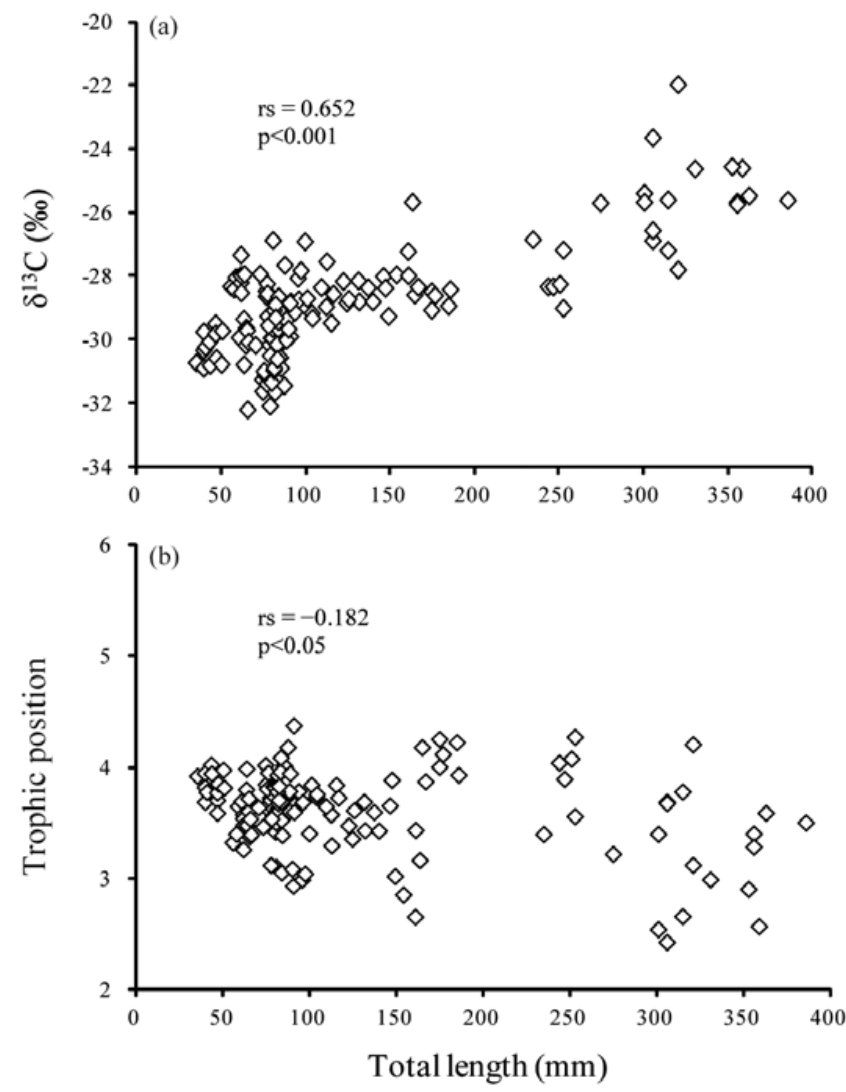

Fig. 4. Correlations between (a) $\delta^{13} \mathrm{C}$ values and (b) trophic positions of largemouth bass and total length. 'rs' represents Spearman's correlation coefficient.

(Crowl, 1989), they may only rarely forage on larval chironomids and dragonflies, which inhabit lake bottoms. We found a positive correlation between $\delta^{13} \mathrm{C}$ values and TL in the largemouth bass population (Fig. 2(a)). In Lake Izunuma, pelagic producers (mainly phytoplankton) had lower $\delta^{13} \mathrm{C}$ values than did littoral producers (epiphytes 
and aquatic plants) (Yasuno et al., 2014; Yasuno et al., 2016). This suggests that the contributions of the pelagic food chain to the diet of largemouth bass decreased, while those of the littoral food chain increased as the bass became larger. Using an SIAR mixing model, we determined the possible contribution of four potential prey sources to largemouth bass tissues. The results showed that the smallest size class $(<100 \mathrm{~mm} \mathrm{TL})$ relied on both zooplankton and small omnivorous fishes, the 100-199 mm TL size class relied mostly on fishes, and the largest size class $(\geq 300 \mathrm{~mm}$ TL) foraged mostly on red swamp crayfish (Fig. 3). Largemouth bass generally shift from zooplanktivory to piscivory during their first year (Keast, 1985; Olson, 1996). Our previous study (Yasuno et al., 2012) in Lake Izunuma, based on stable carbon isotope analyses, showed that the shift to piscivory in the largemouth bass population began at approximately 60-90 mm TL, and the threshold size for piscivory became larger as the season progressed because of the increasing sizes of prey fishes. Therefore, the main diet of bass in Lake Izunuma appears to shift from zooplankton to small fishes and finally to red swamp crayfish.

\section{Trophic positions of largemouth bass}

Ontogenetic diet shifts towards piscivory are generally considered to increase the trophic position of piscivores (Persaud et al., 2012). In Lake Izunuma, the smallest size class $(<100 \mathrm{~mm} \mathrm{TL})$ relied on both zooplankton and small omnivorous fishes, while the 100-199 mm TL size class relied mostly on fishes (Fig. 3). However, there was no significant difference in trophic positions between these size classes (Fig. 4). Our previous study (Yasuno et al., 2012) showed that their $\delta^{15} \mathrm{~N}$ values did not clearly increase with ontogenetic shifts to piscivory. Thus, dietary shifts from zooplanktivory to piscivory do not always increase trophic positions. Our results showed that the trophic positions of small omnivorous fishes were as low as, or lower than, those of copepod zooplankton, although the mean trophic levels of omnivorous fishes and zooplankton were similar (Table 4). In Lake Izunuma, small omnivorous fishes forage on epiphytes (producer; lower trophic level) as well as zooplankton (Yasuno et al., 2016). Foraging on epiphytes may explain the lower trophic positions of small omnivorous fishes. As a result, ontogenetic dietary shifts to piscivory did not increase the trophic position of largemouth bass in Lake Izunuma.

Our results also showed that the mean trophic position of the largest size class of bass $(\geq 300 \mathrm{~mm} T \mathrm{TL})$ was significantly lower than those of smaller size classes (Fig. 4). The largest size class foraged mostly on red swamp crayfish (Fig. 3), which feed on various food sources, including plants and invertebrates (Smart et al., 2002) and thus can function as both primary and secondary consumers. The trophic position of red swamp crayfish was lower than those of the dominant fishes in Lake Izunuma ( $G$. elongates elongates and $P$. parva), although it was similar to the mean trophic positions of small omnivorous fishes. Therefore, ontogenetic shifts from foraging on fishes to red swamp crayfish could actually decrease the trophic position of largemouth bass.

We showed that the trophic position of largemouth bass did not increase with TL in a temperate, eutrophic, shallow lake and the mean trophic position of the largest class size was significantly lower than those of the smaller size classes. Red swamp crayfish, the main food source for bass $\geq 300 \mathrm{~mm}$ TL, had a slightly lower trophic position than small omnivorous fishes and zooplankton. The feeding strategies of consumers are often flexible, being able to switch to lower, more productive trophic levels (Pimm, 1982). In Lake Izunuma, abundant primary producers, such as epiphytes and aquatic plants, are widely available for omnivores, allowing omnivorous fishes and red swamp crayfish to heavily rely on littoral production. Red swamp crayfish are, in fact, known to rely heavily on litter derived from terrestrial plants in Japanese farm ponds (Kobayashi et al., 2011). The positive correlation between $\delta^{13} \mathrm{C}$ and TL of largemouth bass (Fig. 2(a)) suggests that the contributions of littoral rather than pelagic production increased with growth. Consequently, the trophic position of largemouth bass did not increase with the ontogenetic shift from zooplanktivory to piscivory. Furthermore, the trophic position of the largest individuals decreased following their shift to foraging on red swamp crayfish. Our results suggest that the trophic position of largemouth bass should be calculated with caution and their body size should be considered when estimating food chain length or assessing contaminant bioaccumulation. Further clarification of the trophic positions of large piscivores as they relate to body size will greatly improve studies focusing on food-web structures, especially in shallow eutrophic lakes with wide littoral habitats.

Acknowledgements. We thank Dr K. Ito, Department of Agriculture, Tohoku University, for her assistance with the stable isotope analytical facilities. We also thank the Miyagi Prefectural Inland Water Fisheries Experiment Station, Izunuma Fisherman's Association and Bass Busters for their assistance in the field and donation of fish samples. We are grateful to the anonymous referees for their constructive reviews. This study was funded in part by a Grant-in-Aid for Scientific Research from JSPS (No. 20570013 and No. 20570014) and the Tohoku Regional Environmental Office, Ministry of the Environment.

\section{References}

Arita K., Ashizawa J., Fujimoto Y., Shimada T., Hayashi S., Tamaoki M. and Yabe T., 2015. Radioactive cesium accumulation during developmental stages of largemouth bass, Micropterus salmoides. J. JSCE, Ser. G (Environ. Res.), 71, III_225-III_231.

Azuma M. and Motomura Y., 1998. Feeding habits of largemouth bass in a non-native environment: the case of a small lake with bluegill in Japan. Environ. Biol. Fish, 52, 379-389. 
Cabana G. and Rasmussen J., 1996. Comparison of aquatic food chains using nitrogen isotopes. Proc. Natl. Acad. Sci. USA, 93, 10844-10847.

Correa C., Bravo A.P. and Hendry A.P. 2012. Reciprocal trophic niche shifts in native and invasive fish: salmonids and galaxiids in Patagonian lakes. Freshw. Biol., 57, 1769-1781.

Crowl T.A., 1989. Effects of crayfish size, orientation, and movement on the reactive distance of largemouth bass foraging in clear and turbid water. Hydrobiologia, 183, 133-140.

DeNiro M.J. and Epstein S., 1978. Influence of diet on the distribution of carbon isotopes in animals. Geochim. Cosmochim. Acta, 42, 495-506.

Doi H., Chang K.H., Ando T., Ninomiya I., Imai H. and Nakano S.I., 2009. Resource availability and ecosystem size predict food-chain length in pond ecosystems. Oikos, 118, $138-144$.

Feiner Z.S., Rice J.A. and Aday D.D., 2013. Trophic niche of invasive white perch and potential interactions with representative reservoir species. T. Am. Fish. Soc., 142, 628-641.

Fry B. and Sherr E.B., 1984. $\delta 13 \mathrm{C}$ measurements as indicator of carbon flow in marine and freshwater ecosystems. Contrib. Mar. Sci., 27, 13-47.

Fujimoto Y., Kawagishi M. and Shindo K., 2008. Freshwater fishes in Lake Izunuma-Uchinuma basin, Japan: distribution patterns of native species and invasive species. IzunumaUchinuma. Wetland. Res., 2, 13-25. (In Japanese, with English abstract).

García-Berthou E., 2002. Ontogenetic diet shifts and interrupted piscivory in introduced largemouth bass (Micropterus salmoides). Int. Rev. Hydrobiol., 87, 353-363.

Ha J.Y., Izawa T., Kitano S., Nagata T., Sakamoto M. and Hanazato H., 2015. Dietary changes in an introduced largemouth bass (Micropterus salmodes) with biomanipulation in Lake Shirakaba. Jpn. J. Limol., 76, 193-201. (In Japanese, with English abstract).

Hairston N.G. Jr. and Hairston N.G. Sr., 1993. Cause-effect relationships in energy flow, trophic structure, and interspecific interactions. Am. Nat., 142, 379-411.

Hickley P., North R., Muchiri S.M. and Harper D.M., 1994. The diet of largemouth bass, Micropterus salmoides, in Lake Naivasha, Kenya. J. Fish. Biol., 44, 607-619.

Jang M.H., Joo G.J. and Lucas M.C., 2006. Diet of introduced largemouth bass in Korean rivers and potential interactions with native fishes. Ecol. Freshw. Fish, 15, 315-320.

Jennings S., Pinnegar J.K., Polunin N.V.C. and Boon T.W., 2001. Weak cross-species relationships between body size and trophic level belie powerful size-based trophic structuring in fish communities. J. Animal. Ecol., 70, 934-944.

Jones J.I. and Waldron S., 2003. Combined stable isotope and gut contents analysis of food webs in plant-dominated, shallow lakes. Freshw. Biol., 48, 1396-1407.

Keast A., 1985. The piscivore feeding guild of fishes in small freshwater ecosystems. Environ. Biol. Fish., 12, 119-129.

Keast A. and Eadie J.M., 1985. Growth depensation in year-0 largemouth bass: the influence of diet. Trans. Am. Fish. Soc., 114, 204-213.

Kline T.C., Wilson W.J. and Goering J.J., 1998. Natural isotope indicators of fish migration at Prudhoe Bay, Alaska. Can. J. Fish. Aquat. Sci., 55, 1494-1502.

Kobayashi R., Maezono Y. and Miyashita T., 2011. The importance of allochthonous litter input on the biomass of an alien crayfish in farm ponds. Popul. Ecol., 53, 525-534.

Maezono Y., Kobayashi R., Kusahara R. and Miyashita T., 2005. Direct and indirect effect of exotic bass and bluegill on exotic and native organisms in farm ponds. Ecol. Appl., 15, 638-650.

Magoro M.L., Whitfield A.K. and Carassou L., 2015. Predation by introduced largemouth bass, Micropterus salmoides on indigenous marine fish in the lower Kowie River, South Africa. Afr. J. Aquat. Sci., 40, 81-88.

Matsuda K., Takagi K., Tomiya A., Enomoto M., Tsuboi J.I., Kaeriyama H., Ambe D., Fujimoto K., Ono T., Uchida K., Morita T. and Morita T., 2015. Comparison of radioactive cesium contamination of lake water, bottom sediment, plankton, and freshwater fish among lakes of Fukushima Prefecture, Japan after the Fukushima fallout. Fish. Sci., 81, 737-747.

Mizuno T. and Kubo H., 2013. Overview of active cesium contamination of freshwater fish in Fukushima and Eastern Japan. Sci. Rep., 3, 1742.

Olson M.H., 1996. Ontogenetic niche shifts in largemouth bass: variability and consequences for first-year growth. Ecology, 77, 179-190.

Parnell A.C., Inger R., Bearhop S. and Jackson A.L., 2010. Source partitioning using stable isotopes: coping with too much variation. PLoS ONE, 5, e9672.

Pauly D. and Christensen V., 1995. Primary production required to sustain global fisheries. Nature, 374, 255-257.

Persaud A.D., Dillon P.J., Molot L.A. and Hargan K.E., 2012. Relationships between body size and trophic position of consumers in temperate freshwater lakes. Aquat. Sci., 74, 203-212.

Phillips D.L. and Gregg J.W., 2001. Uncertainty in source partitioning using stable isotopes. Oecologia, 127, 171-179.

Pimm S.L., 1982. Food Webs, Chapman and Hall, London.

Post D.M., 2002a. The long and short of food-chain length. Trends. Ecol. Evol., 17, 269-277.

Post D.M., 2002b. Using stable isotopes to estimate trophic position: models, methods, and assumptions. Ecology, 83, 703-718.

Rasmussen J.B., Rowan D.J., Lean D.R.S. and Carey J.H., 1990. Food chain structure in Ontario lakes determines PCB levels in lake trout (Salvelinus namaycush) and other pelagic fish. Can. J. Fish. Aquat. Sci., 47, 2030-2038.

R Development Core Team, 2015. R: A Language and Environment for Statistical Computing. R Foundation for Statistical Computing, Vienna, Austria.

Scheffer M., 1998. Ecology of Shallow Lakes, Chapman Hall, London, UK.

Schindler D.E., Hodgson J.R. and Kitchell J.F., 1997. Densitydependent changes in individual foraging specialization of largemouth bass. Oecologia, 110, 592-600.

Schramm H.L. Jr. and Maceina M.J., 1986. Distribution and diet of Suwannee bass and largemouth bass in the lower Santa Fe River, Florida. Environ. Biol. Fish., 15, 221-228.

Shelton W.L., Davies W.D., Kling T.A. and Timmons T.J., 1979. Variations in the growth of the initial year class of largemouth bass in West-Point-Reservoir, Alabama and Georgia. T. Am. Fish. Soc., 108, 142-149.

Shidara S., 1992. Social conditions surrounding Izunuma and Uchinuma Lakes. In: Advisory Committee for Environmental Preservation Measures (ed.): Report for 
Environmental Preservation Measures of Izunuma and Uchinuma Lakes. Miyagi Prefecture, Japan, pp. 155-164. (in Japanese).

Smart A.C., Harper D.M., Malaisse F., Schmitz S., Coley S. and De Beauregard A.C.G., 2002. Feeding of the exotic Louisiana red swamp crayfish, Procambarus clarkii (Crustacea, Decapoda), in an African tropical lake: lake Naivasha, Kenya. Hydrobiologia, 488, 129-142.

Takahashi K., Onodera T. and Kumagai A., 2001. Appearance of largemouth bass and changes in species composition of fish caught by set net at Izunuma and Uchinuma. Miyagi. Pref. Rep. Fish. Sci., 1, 111-118. (in Japanese).

Torigoe K. and Shiraiwa T., 2010. Ecological studies of Largemouth bass (Micropterus salmoides) in Nakadoorijima, Goto islands, Nagasaki Pref. Bull. Grad. Sch. Educ. Hiroshima. Univ. Part., 2(59), 1-7.

Vanderklift M.A. and Ponsard S., 2003. Sources of variation in consumer-diet $\delta^{15} \mathrm{~N}$ enrichment: a meta-analysis. Oecologia, 136, 169-182.

Vander Zanden M.J. and Rasmussen J.B., 2001. Variation in $\delta^{15} \mathrm{~N}$ and $\delta^{13} \mathrm{C}$ trophic fractionation: implications for aquatic food web studies. Limnol. Oceanogr., 46, 2061-2066.

Vander Zanden M.J. and Vadeboncoeur Y., 2002. Fishes as integrators of benthic and pelagic food webs in lakes. Ecology, 83, 2152-2161.

Vander Zanden M.J., Hulshof M., Ridgway M.S. and Rasmussen J.B., 1998. Application of stable isotope techniques to trophic studies of age-0 smallmouth bass. T. Am. Fish. Soc., 127, 729-739.

Vander Zanden M.J., Casselman J.M. and Rasmussen J.B., 1999. Stable isotope evidence for the food web consequences of species invasions in lakes. Nature, 401(6752), 464-467.

Vander Zanden M.J., Olden J.D., Thorne J.H. and Mandrak N.E., 2004. Predicting occurrences and impacts of smallmouth bass introductions in north temperate lakes. Ecol. Appl., 14, 132-148.

Vander Zanden M.J., Vadeboncoeur Y. and Chandra S., 2011. Fish reliance on littoral-benthic resources and the distribution of primary production in lakes. Ecosystems, 14, 894-903.
Wang Y., Yu X. and Xu J., 2011. Decreased trophic position as a function of increasing body size of a benthic omnivorous fish from the largest freshwater lake in China. Environ. Biol. Fish., 91, 505-512.

Wasserman R.J., Strydom N.A., and Weyl O.L.F., 2011. Diet of largemouth bass, Micropterus salmoides (Centrarchidae), an invasive alien in the lower reaches of an Eastern Cape river, South Africa. Afr. Zool., 46(2), 378-386.

Wheeler, A.P. and Allen, M.S., 2003. Habitat and diet partitioning between shoal bass and largemouth bass in the Chipola River, Florida. T. Am. Fish. Soc., 132(3), 438-449.

Whittier, T.R. and Kincaid, T.M., 1999. Introduced fish in northeastern USA lakes: regional extent, dominance, and effect on native species richness. T. Am. Fish. Soc., 128(5), 769-783.

Yasuno N., Chiba Y., Shindo K., Shimada T., Shikano S. and Kikuchi E., 2009. Changes in the trophic state and the benthic fauna in Lake Izunuma, with special reference to the chironomid species. Izunuma-Uchinuma. Wetland. Res., 3, 49-63. (In Japanese, with English abstract).

Yasuno N., Chiba Y., Shindo K., Fujimoto Y., Shimada T., Shikano S. and Kikuchi E., 2012. Size-dependent ontogenetic diet shifts to piscivory documented from stable isotope analyses in an introduced population of largemouth bass. Environ. Biol. Fish., 93, 255-266.

Yasuno N., Shikano S., Shimada T., Shindo K. and Kikuchi E., 2013. Comparison of the exploitation of methane-derived carbon by tubicolous and non-tubicolous chironomid larvae in a temperate eutrophic lake. Limnology, 14, 239-246.

Yasuno N., Shindo K., Takagi Y., Kanaya G., Shikano S., Fujimoto Y. and Kikuchi E., 2014. Ontogenetic changes in the trophic position of a freshwater Unionidae mussel. Fundam. Appl. Limnol., 184, 341-349.

Yasuno N., Chiba Y., Fujimoto Y., Shindo K., Shimada T., Shikano S. and Kikuchi E., 2016. Zoobenthos are minor dietary components of small omnivorous fishes in a shallow eutrophic lake. Mar. Freshw. Res, 67(10), 1562-1568.

Yonekura R., Kita M. and Yuma M., 2004. Species diversity in native fish community in Japan: comparison between non-invaded and invaded ponds by exotic fish. Ichthyol. Res., $51,176-179$. 